\title{
TANULÁS FÉLÁRNYÉKBAN - TANÓRAI, TANÓRÁN KÍVÜLI ÉS ISKOLÁN KÍVÜLI TANULÁS AZ ÁLTALÁNOS ISKOLÁKBAN
}

\author{
IMRE ANNA
}

A tanulmány a tanórán kívüli tanulás lehetőségeit vizsgálja az élethosszig tartó tanulás, illetve a tanulói részvétel értelmezési keretére támaszkodva három - tanórai, tanórán kívüli és iskolán kívüli - tanulási környezet sajátosságainak és eltéréseinek segítségével, a tanulók nézőpontján keresztül. Az elemzés elsősorban három általános iskola felső tagozatos tanulói körében online kérdőívvel felvett adatokra épít, de az összehasonlíthatóság érdekében országos tendenciákat is bemutat az Országos kompetenciamérés adatainak segítségével az érintett oktatási szintre és időszakra vonatkozóan. Az elemzés tapasztalatai rámutatnak a tanulói részvétel különbségeivel összefüggő eltérésekre, valamint az egyes tanulási környezetek néhány jellemzőjére, ezek tartós egymás mellett élésére, s a tanulók életében betöltött jelentőségükre a napi időfelhasználás és a tanulói értékelés tükrében.

Kulcsszavakः tanulási környezetek, tanulói részvétel, tanórán kívüli tanulás, tanórai tanulás

The study examines the possibilities of extracurricular learning, drawing on the interpretive framework of lifelong learning and student participation, using the characteristics and differences of three learning environments - classroom, extracurricular and out-ofschool - through students' perspectives. The analysis builds primarily on data collected by online questionnaire among primary school pupils, but also presents national data and trends for the primary education level and period concerned for comparability. The experience of the analysis points to differences in student participation and some of the characteristics of the learning environments, and their lasting coexistence and importance in the lives of students in the light of daily time use and student evaluation.

Keywords: learning environments, student participation, extracurricular learning, classroom learning 


\section{Bevezetés}

$\mathrm{A}$ $z$ iskolai szervezésben mủködő tanórán kívüli tanulás a tanórai és az iskolán kívüli tanulás határán helyezhető el, ami a tanórai tanulás felől nézve kívülrôl, az iskolán kívüli tanulás felől nézve belülről működik, valahol a „félárnyékban”, s múködéséhez figyelemre érdemes tapasztalatok kapcsolódnak. Az árnyékoktatáshoz köthető iskolán kívüli foglalkozások az iskolától függetlenül, jellemzően a magánszektorhoz kapcsolódóan kínálnak tanulással összefüggő, színvonalas szolgáltatásokat, díjazás ellenében, így csak szükebb kör, jellemzően magasabb státuszú társadalmi csoportok számára elérhető módon. A tanórán kívüli tanulás - az előbbihez hasonlóan többletszolgáltatást kínál a tanulók számára, de mindez az iskola keretén belül, az iskola eszközeinek felhasználásával történik, s jellemzően térítés nélkül. Az iskolai keretek és az ingyenes szolgáltatás következtében a tanórán kívüli tanulás keretében kínált foglalkozások esetében szélesebb a hozzáférés esélye, így ezek eltérő, szélesebb társadalmi csoportok gyermekei számára is elérhetőek.

A tanórán kívüli foglalkozások nem pusztán önmagukban érdemesek a figyelemre. Más tanulási környezetekhez kapcsolódó szerepük legalább annyira vagy még fontosabb lehet, ez az élethosszig tartó tanulás nézőpontja felől könnyebben felismerhető. Az élethosszig tartó tanulás megközelítéséből közelítve tanulás bárhol, bármikor történhet, nem csak az iskolában (Halász 2009). Életünk során eltérő, formális, nemformális és informális környezetekkel interakcióba lépve tanulunk, ezek közül a formális tanóra világa csak egy a sok közül, csak kis része a tanulással összefüggő környezetek „ökoszisztémájának". A tanórán kívüli tanulás a nem formális tanulási környezetek több jellemzőjével rendelkezik: jellemzően önkéntes választásra épül, amely a formális rendszeren kívül történik, de szándékos és strukturált tanulást tesz lehetővé, intézményhez kapcsolódva (LLLP 2019).

Beth Miller szerint a tanórán kívüli foglalkozások egy alternatív környezetet tudnak felkínálni a tanulók és a tanulás számára, ami jobban összhangban van a fiatalok igényeivel, ahol személyes figyelmet kaphatnak felnőttek részéről, a pozitív kortárscsoportkapcsolatok s -tevékenységek révén az önértékelésük növekedhet. A délutáni programok képesek hidat verni vagy határzónát kialakítani csoport-, családi és iskolai környezetek között (Miller 2003). A tanórán kívüli foglalkozások nem különülnek el élesen más fejlödési kontextusoktól, azok által is befolyásoltan működnek, így a különböző kontextusok egymást esetenként gátolhatják, de segíthetik vagy akár kompenzálhatják is (Feldman-Matjasko 2005). Például, mivel az iskolák növekvő mértékben fókuszálnak a kognitív képességekre, a tanórán kívüli programoknak egy fontos hiánynak, a nem kognitív képességek fejlesztési feladatának betöltésére van esélyük. A nem kognitív, társas és személyes képességek fejlesztésére alkalmas programok lehetőségeket kínálnak az életben fontos olyan képességek fejlesztésére, mint például a kitartás, reziliencia, vagy az önbecsülés kialakítása (Huang 2013; Cefai et al. 2018). Egyes szerzők tapasztalatai szerint a tanórán kívüli foglalkozások elsősorban ezen nem kognitív kompetenciák fejlesztéséhez járulnak hozzá, ezek révén járulnak hozzá a kognitív képességekhez, így a tanulmányi eredményességhez is (Covay-Carbonaro 2010; OECD 2015).

Más szerzők a tanórán kívüli tanulással összefüggésben a tanulók általános fejlödési lehetőségét és motiváltságának fennmaradását, aktiv bevonódásának lehetőségét emelik 
ki (Eccles 2005; Mahoney et al. 2005; Miller 2003; Skinner-Pitzer 2013; Józsa et al. 2020). Néhányan ezzel összefüggésben az időráfordítás fontosságát is hangsúlyozzák (Eccles 2005; Huang 2013). Egy szakirodalmi forrásból származó megállapítás alapján eredményesség a legalább a rendelkezésre álló idő $50 \%$-ában való részvétel esetében várható (CRIC Clearinghouse 2014, idézi Miller 2003).

A jelen elemzés a tanórán kívüli tanulásra fókuszál, tanulói tapasztalatokra építve, kitekintéssel van a tanórai, tanórán kívüli és az iskolán kívüli tanulásra is. Az elemzésben a tanulói részvétel kérdésére helyeztük a hangsúlyt, az alábbi kérdések segítségével:

- Mi jellemzi a vizsgált tanulók körében a tanórai, tanórán kívüli és iskolán kívüli részvételt az általános iskola felső tagozatán?

- Hogy látják a tanulók az egyes tanulási környezeteket, a tanulás lehetőségeit ezek esetében?

- Befolyásolja-e a tanórán kívüli részvétel és ennek gyakorisága az iskolával, tanulással kapcsolatos attitüdöket?

Az elemzés első részében a tanórán és iskolán kívüli tanulással összefüggésben országos tendenciákat vizsgálunk. Az elemzés második és harmadik része egy kérdőíves kutatáshoz kapcsolódik. A második részben a tanulói részvétel tendenciáit elemezzük a tanórán és az iskolán kívüli tanulás vonatkozásában. A harmadik részben a tanórán kívüli részvétel, ill. a tanuláshoz és az iskolához való viszony összefüggéseit vizsgáljuk, végül a vizsgált tanulási környezetekkel kapcsolatos tapasztalatokat vetjük össze a tanulói preferenciák segítségével.

\section{Országos tendenciák}

A tanórán és az iskolán kívüli foglalkozásokkal kapcsolatban néhány általános sajátosság követésére és elemzésére a statisztikai adatok és nagy mintán megvalósított rendszeres adatfelvételek, például az Országos kompetenciamérés adnak lehetőséget. ${ }^{1}$ $\mathrm{A} z$ Országos kompetenciamérés 2018-as adatfelvételének adatai szerint tanórán kívüli foglalkozásokon az általános iskola 6. évfolyamán a tanulók jelentős, 19,5 és 34,7\% közti arányban vettek részt, iskolán kívüli foglalkozásokon a sport kivételével alacsonyabb 12,2 és 42,9\% közötti arányban. Iskolán belül 2018-ban a tanulók legnagyobb, egyharmados arányban sportfoglalkozásokra jártak, ehhez közelítő arányban voltak érintettek korrepetálásban és fejlesztő foglalkozásokban, tehetséggondozásra egyötöd arányban jártak. A 8. évfolyamon a tanórán kívüli részvételi arány a 6 . évfolyaménál alacsonyabb. Az iskolán kívüli tanulási lehetőségek többségében a tanulók kisebb hányada érintett mindkét évfolyamon, a sport kivételével. A két évfolyam között a részvétel csökkenése figyelhető meg a tanórán kívüli foglalkozások többségében, az iskolán kívüli foglalkozások vonatkozásában ugyanakkor megfigyelhető a többségében a stabilitás (lásd 1. táblázat).

$\mathrm{A} z$ iskolán és a tanórán kívüli szektorokban, ill. az egyes foglalkozások esetében is igen eltérő az érintett tanulók társadalmi összetétele. A társadalmi összetételt a 6 . év-

1 Az Országos kompetenciafelmérés (OKM) tanulói kérdőíve csak néhány tanórán, ill. iskolán kívüli foglalkozás esetében kérdez rá a tanulói részvételre, ezek teljes képet nem adnak, de az érintett tevékenységek a tanórai és iskolán kívüli foglalkozások legfontosabb típusait jól szemléltetik, s részletes, mélyebb elemzést is lehetővé tesznek az iskolán és tanórán kívüli foglalkozások egy szűkebb körére. 
1. táblázat: Néhány tanórán és iskolán kívüli foglalkozáson való részvételi arány az általános iskolában, OKM tanulói kérdőív, 2018 (az összes tanuló \%-ában)

\begin{tabular}{llcc}
\hline & & 6. évf. & 8. évf. \\
\hline Tanórán kívül & korrepetálás, fejlesztő foglalkozás & 31,7 & 25,5 \\
& tehetséggondozó óra & 19,5 & 17,3 \\
& iskolai szervezésű szabadidős sportfoglalkozás & 34,7 & 28,8 \\
\hline Iskolán kívül & matematika & 15,2 & 16,0 \\
& idegen nyelv & 14,5 & 15,2 \\
& zene & 12,2 & 8,8 \\
& sport & 41,9 & 35,3 \\
& egyéb & 13,0 & 10,3 \\
\hline
\end{tabular}

folyamon, az adott foglalkozáson részt vevők arányában vizsgáltuk. Az iskolán kívüli foglalkozásokkal összevetve a tanórán kívüli tanulásban részt vevők összetétele heterogénebb, foglalkozásoktól függően is eltérő. Az iskolai szervezésű tanórán kívüli, lemaradást megelőző, korrekciós típusú foglalkozásokon részt vevők édesanyjának közel fele (49\%) legfeljebb szakmunkásbizonyítvánnyal rendelkezik, a tehetséggondozásban részt vevők háromnegyede (74\%-a) érettségizett vagy diplomás szülők gyermeke, az iskolai szabadidős foglalkozás a résztvevők társadalmi összetétele szempontjából sokszínű, kiegyensúlyozottabb képet mutat. Az iskolán kívüli foglalkozások esetében a részvétel eltolódik a diplomával rendelkező csoportok irányába: az idegen nyelvi, zenei és sportfoglalkozások esetében az érintett tanulók fele 48-60\% közötti arányban diplomás szülők gyermeke (lásd 2. táblázat).

2. táblázat: A tanórán és iskolán kívüli foglalkozáson való részvétel, a részt vevő tanulók társadalmi összetétele, 2018 (\%)

\begin{tabular}{|c|c|c|c|c|c|c|}
\hline & & \multicolumn{5}{|c|}{ Anya iskolázottsága, 6. évfolyam } \\
\hline & & $\begin{array}{l}\text { Max. ált. } \\
\text { isk. (\%) }\end{array}$ & $\begin{array}{l}\text { Szakiskola } \\
\text { (\%) }\end{array}$ & $\begin{array}{l}\text { Érettségi } \\
(\%)\end{array}$ & $\begin{array}{l}\text { Diploma } \\
(\%)\end{array}$ & $\begin{array}{c}\text { Összes } \\
(\%)\end{array}$ \\
\hline \multirow{3}{*}{ 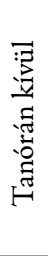 } & $\begin{array}{l}\text { korrepetálás, } \\
\text { fejlesztő foglalkozás }\end{array}$ & 20,7 & 28,1 & 29,2 & 22,0 & 100,0 \\
\hline & $\begin{array}{l}\text { tehetséggondozó } \\
\text { óra }\end{array}$ & 9,2 & 17,3 & 29,5 & 44,0 & 100,0 \\
\hline & $\begin{array}{l}\text { iskolai szabadidős } \\
\text { sportfoglalkozás }\end{array}$ & 18,3 & 25,0 & 29,1 & 27,5 & 100,0 \\
\hline \multirow{5}{*}{ 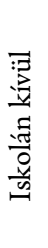 } & matematika & 8,1 & 21,7 & 32,9 & 37,3 & 100,0 \\
\hline & idegen nyelv & 4,3 & 13,3 & 32,1 & 50,3 & 100,0 \\
\hline & zene & 5,7 & 10,0 & 24,0 & 60,3 & 100,0 \\
\hline & sport & 6,8 & 14,7 & 30,6 & 47,9 & 100,0 \\
\hline & egyéb & 10,0 & 16,9 & 28,1 & 44,9 & 100,0 \\
\hline
\end{tabular}




\section{Kutatási keretek}

Saját kutatásunk tapasztalatainak segítségével az előbbiekhez képest más megközelítésből is vizsgálhattuk a tanórán kívüli és részben az iskolán kívüli foglalkozások általános iskolai világát. A kutatás a tanórán kívüli tanulás kérdését elsősorban a kérdezést megelőző három év tapasztalatainak vonatkozásában igyekezett megismerni. A kis számú iskolában online kérdőív segítségével gyűjtött adatok mintája nem reprezentatív, de néhány meghatározó dimenziót (pl. társadalmi háttér, területi jellemzők) figyelembe vevő módon lett kialakítva (lásd 3. táblázat). ${ }^{2}$

3. táblázat: A kérdőíves adatfelvétel mintája, 2019/2020, N (\%)

\begin{tabular}{|c|c|c|c|c|c|c|}
\hline & \multicolumn{2}{|c|}{ Igazgatók } & \multicolumn{2}{|c|}{ Pedagógusok } & \multicolumn{2}{|c|}{ Tanulók } \\
\hline & $N$ & $\%$ & $N$ & $\%$ & $N$ & $\%$ \\
\hline Budapesti kerület & 5 & 18,5 & 55 & 32 & 114 & 36,3 \\
\hline M. járás & 16 & 59,3 & 87 & 50 & 199 & 63,4 \\
\hline J. járás & 6 & 22,2 & 30 & 17 & 0 & 0 \\
\hline Összesen & 27 & 100 & 172 & 100 & 313 & 100 \\
\hline
\end{tabular}

A tanulói tapasztalatokat két térségben működő, válaszadásra külön felkért iskolák felső tagozatos tanulóinak válaszai segítségével vizsgáltuk. A kérdőívet három intézmény - két fővárosi iskola, ill. egy, az M. járásban működő intézmény három tagiskolájának tanulói töltötték ki. ${ }^{3}$ A tanulók valamivel kevesebb mint fele (45,2\%) az 5-6. évfolyamra, $\mathrm{s}$ valamivel több mint fele $(53,5 \%)$ a 7-8. évfolyamra járt.

\section{A tanulók részvétele a tanórai, tanórán és iskolán kívüli foglalkozásokon}

A tanulói részvétel kérdésének több tanulási környezetet érintő vizsgálata nem olyan egyértelmű, mint első pillantásra tünik. A kérdéssel összefüggésben egy, az időráfordításra épülő tipizálást, valamint egy, a tanulói részvétel gyakoriságtól eltérő tipizálási lehetőséget is (Finn 1989) ${ }^{4}$ figyelembe vettük. Az elemzés során a tanulók tanuláshoz és iskolához való általános viszonyát, a tanórai és a tanórán kívüli tanulásban való eltérő részvételét

2 A kutatás mintája és kérdőíve előzményhez is kapcsolódott: egy 2013/2014-es tanévben és egy három évvel későbbi, 2016/2017-es tanévben hasonló témában készült adatgyüjtés mintáján és azok tapasztalatait is figyelembe véve készült. A kérdezés három eltérő helyzetű járásra terjedt ki: a fővárosi kerület a tanulók társadalmi összetétele szempontjából országos átlag feletti, az egyik vidéki járás (J. járás) átlagos, a másik vidéki járás (M. járás) átlag alatti jellemzőkkel rendelkezett.

3 A tanulók társadalmi összetételének vizsgálata sajnos az elemzés során korlátokba ütközött: a tanulók jelentős része (36,4\%-a) nem tudta megmondani édesanyja iskolai végzettségét, de az elemezhető adatokból is kirajzolódik a két térség közti eltérés iránya.

4 Jeremy Finn a tanulók iskolai részvételének 4 szintjét különböztette meg: 1. a tanórán való fizikai jelenlét, kérdésekre adott válaszok; 2. órára való készülés, a tanárral való dialógus, ill. kérdések feltevése a tanórán, órára való készülés; 3. tantárgyi vonatkozású klubokban, közösségi tevékenységekben való részvétel; 4. az iskolai élet irányításában való részvétel a tanulót érintő kérdések vonatkozásában és mértékében (pl. tanulmányi vonatkozású döntések, viselkedési szabályok kialakítása) (Finn 1989). 
is vizsgáltuk. Az általános iskolai oktatásban az iskolai részvétel nem önkéntes, hanem kötelező, így a formális részvétel közel 100\%-os, ezért Finn nyomán érdemes különbséget tenni a formális és az érdemi részvétel között, ahol az érdemi részvétel leginkább a tanulással összefüggő aktív munkában való részvétellel, a tanulásba való bevonódással jellemezhető, nem a puszta jelenléttel. A tanórán kívüli tanulásban való részvétel - mivel nagyrészt önkéntességre épülő tevékenység - megítélésünk szerint a tanulásban való részvételnek tekinthető, intenzitása a részvétel gyakoriságával mérhető.

\section{Tanórai tanulói részvétel}

A tanórai munkában való részvétel kérdéseire adott válaszok alapján némileg ellentmondásos tendencia rajzolódik ki. A tanulói válaszokból az bontakozik ki, hogy a tanulók érdemi részvétele a tanórai munkában igen eltérő, s évfolyamok mentén változik. Az általunk vizsgált iskolákban a felső tagozaton átlagosan a tanulók 14\%-a úgy van jelen a tanórán, hogy aktívan nem vesz részt benne. A tanulók szük harmada (31\%) említette magáról, hogy az órák többségén aktívan részt vesz, azaz érdemben is bekapcsolódik az óra menetébe, a tanulók fele (52\%) úgy nyilatkozott, hogy az aktivitás csak néhány órán jellemző rá. A lányokra jellemzőbb az általános aktivitás (35,6\%), mint a fiúkra, akik közt valamivel magasabb a szelektív aktivitás és az inaktivitás (55\%, ill. 15\%). Az aktivitás általános hiányával jellemezhető tanulói csoport a felső tagozat magasabb évfolyamain nagyságrendileg hasonló. Összességében úgy tünik, a tanárok összességében - ha nem is minden órán egyformán - számíthatnak a felső tagozaton tanulók döntő többségének (83\%-ának) valamilyen mértékủ részvételére, a tanulók átlagosan egyharmadát kitevő, az órák többségén aktívan dolgozó csoport mellett a szelektívebben bevonódó tanulók csoportjára, ami a tanulók 50\%-át teszi ki. Nehezítheti a helyzetet az utóbbiak esetében az aktivitást mutatók belső átrendeződése, az órai részvétel a felső tagozat folyamán az 5-6. évfolyamon még a tanulók kétötödére jellemző a minden órára kiterjedő aktivitás, a 7-8. évfolyamon már csak a tanulók egynegyedére volt jellemző (lásd 4. táblázat).

4. táblázat: A tanulók tanórai részvételének jellemzői, tanulói válaszok (\%)

\begin{tabular}{lccc}
\hline & 5-6. évf. (\%) & 7-8. évf. (\%) & Átlag (\%) \\
\hline Az órák többségén aktívan részt veszek az órai munkában & 39,4 & 24,7 & 31,4 \\
Csak néhány órán veszek részt aktívan & 43,8 & 57,8 & 51,5 \\
Általában nem vagyok aktív az órákon & 13,9 & 13,3 & 13,5 \\
Nem tudom & 2,9 & 4,2 & 3,6 \\
\hline
\end{tabular}

A feltett kérdés: Az alábbiak közül melyik állítás jellemző leginkább rád? $p=0,05$

A tanórai részvétel mértéke több mindennel összefügghet, a vizsgálatban egy, a gyakorlat oldaláról viszonylag könnyen befolyásolható dimenziót vizsgáltunk a tanulói vélemények tükrében, az órán alkalmazott módszerek kérdését. A tanórai munkával kapcsolatban azt vizsgáltuk, hogy milyen foglalkozásokat, módszereket kedvelnek a tanulók, s hogyan alakul ezek alkalmazása a felső tagozat folyamán. Az 1-5 válaszokból az körvonalazódik, hogy a tanulók elsősorban azokat a foglalkozásokat kedvelik, amikor a tanárok bemutatnak valamit $(4,5)$, ezt követően az olyan órát, ahol a tanulók beszélhetnek, elmondhatják a véleményüket $(4,1)$, s ,jó” értéket kapott még a csoportfoglalkozást tar- 
talmazó tanóra $(4,00)$ is. A kevésbé kedvelt, 4-es érték alatti foglalkozások körébe azok tartoztak, amikor elsősorban a tanár beszél $(3,8)$, amikor a tanulók egyedül dolgoznak $(3,4)$, ill. amikor kiselőadást kell tartaniuk $(3,3)$. Az emlitett módszerek tanórán való alkalmazásának jellemző gyakoriságát is megvizsgáltuk, kíváncsian arra, hogy a tanulók által kedvelt foglalkozások milyen gyakran fordulnak elő az iskolai gyakorlatban. A tanulók válaszaiból a gyakorlati alkalmazással kapcsolatban kirajzolódó kép eltér a tanulók által preferált sorrendtől. A sorrend szempontjából a kevésbé kedvelt foglalkozástípusok bizonyultak gyakran előfordulónak, amikor a tanár beszél $(4,5)$ és amikor a tanulók egyedül dolgoznak $(4,1)$. Közepesen gyakoriak a csoportfoglalkozások $(3,1)$, s kiselőadásokra kerül sor a legritkábban (lásd 1. ábra).

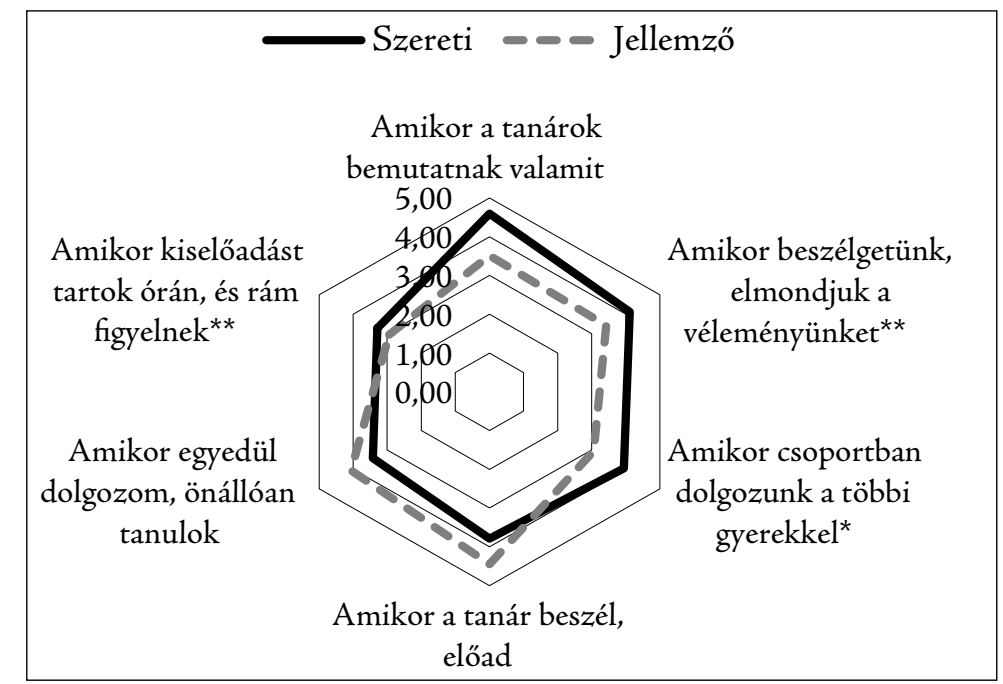

1. ábra: A tanulók által kedvelt és jellemzően előforduló tevékenységek (1-5 átlagok).

$$
{ }^{*} p<0,05,{ }^{* *} p<0,01
$$

Tanulságos a két adatsor összevetése is: a tanulók szempontjából a legnagyobb negatív eltérés a leginkább kedvelt bemutató foglalkozás esetében volt. Ezt követően a csoportfoglalkozás és a tanulókkal történő beszélgetés kapcsán mondható el, hogy a tanulói elvárásoktól jelentős mértékben elmaradt a gyakorlat. Másfelől ugyanakkor két kevésbé kedvelt foglalkozás (a tanár beszél, előad, ill. önálló tanulás) kapcsán a helyzet fordított volt, ezek esetében a gyakorlat haladta meg jelentős mértékben a tanulói igényeket.

Természetesen nem várható, hogy teljes összhang legyen a tanulói igények és a pedagógiai gyakorlat között, mégis figyelemre méltó az eltérés a tendenciában. Az eltérés két esetben, két irányban is megragadható. Egyik esetben egyes tanári módszerek alkalmazása elmarad a tanulói igényektől (pl. csoportmunka), a másik eset ennek fordítottja, a tanulók által kevésbé kedvelt módszerek jellemzőbbek a gyakorlatban (pl. a tanár beszél, egyedül dolgozom). Az évfolyamok szerinti bontás a 7-8. évfolyamon az utóbbiak magasabb szintjét mutatja.

Megkértük a tanulókat arra is, hogy értékeljenek néhány, a tanulók tanulási folyamatban való részvételét növelő megoldást a fontosság és a megvalósulás esélyének szempontjából. A tanulók 4-es skálán 3-as és 4-es értékek között értékelték az egyes állítások fontosságát, a legfontosabbnak a tanulók egyéni képességét figyelembe vevő tanítást látták, 


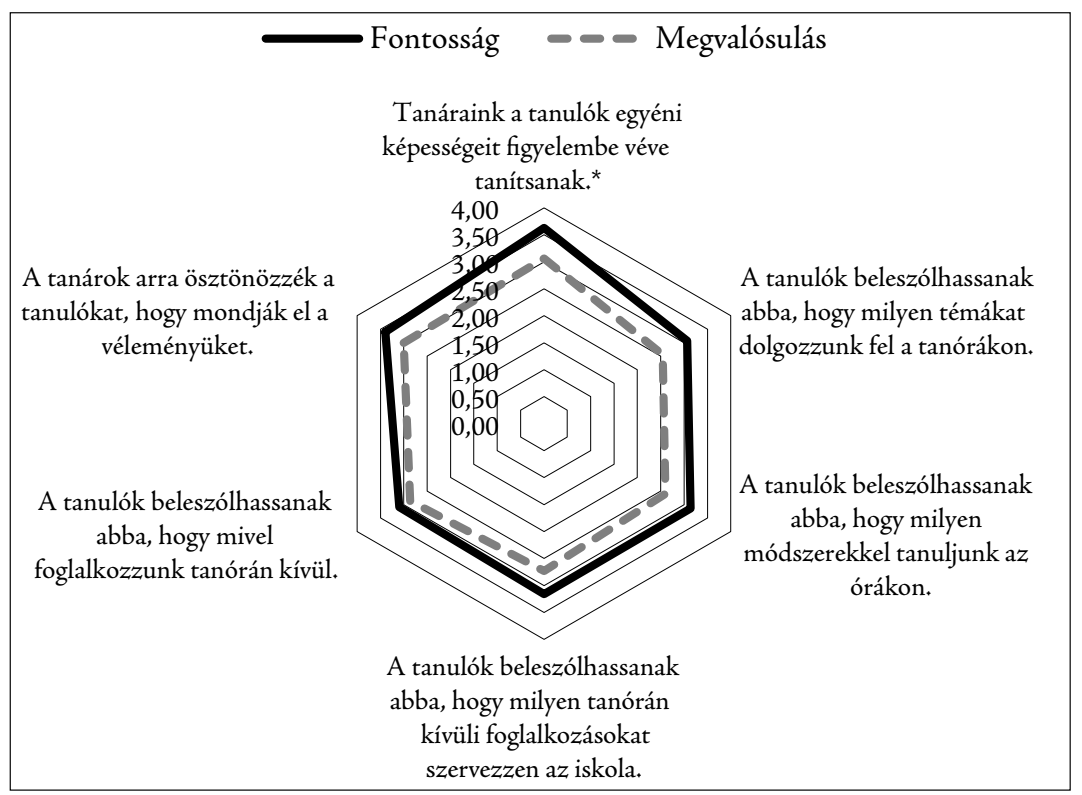

2. ábra: Tanulói vélemények a tanórai tanulás egyes lehetőségeiről (1-4 skálaátlagok).

$$
{ }^{*} p<0,05
$$

ezt követően azt, hogy a tanulók beleszólhassanak az iskola által szervezett tanórán kívüli foglalkozásokba és a tanórákon alkalmazott módszerekbe, témákba. Az említett megoldások megvalósulását jellemzően 2-es és 3-as értékek között értékelték, a fontosság és a megvalósulás közti eltérés mértéke a legnagyobb az egyéni képesség figyelembevétele esetében volt, a legkisebb a tanórán kívüli foglalkozásokba való beleszólás lehetősége esetében (lásd 2. ábra).

\section{Tanórán kivüli tanulásban való tanulói részvétel - foglalkozások, gyakoriság}

Az egyes tanórán kívüli foglalkozásokon való részvétel a korábban megismert tendenciákat tükrözi (Imre 2015; Imre 2018). A tanulók a legnagyobb arányban sporttevékenységekben vettek részt, jelentős volt még a napközi, a tanulószoba, a szakkör, a felvételi előkészítő. Ritkábbnak bizonyult az idegen nyelvoktatás, a felzárkóztató és fejlesztő foglalkozás, ill. a pályaválasztást segítő foglalkozás.

A vizsgált két térségben néhány ponton markánsan eltért a kínálat: a napközi, a tanulmányi verseny, a felvételi előkészítő elsősorban a fővárosi tanulók számára volt elérhető, a tanulószoba és a művészeti foglalkozások inkább a vidéki tanulók számára. A felső tagozat első két és utolsó két évfolyamán is módosult a kínálat és a részvétel. $\mathrm{Az}$ 5-6. évfolyamon még jelentős volt a gondoskodó típusú foglalkozásokon való részvétel (pl. napközi ${ }^{5}$ ), s bár a legnagyobb arányt a tanulmányi célú foglalkozások tették ki, de jelentős volt a gazdagító jellegű foglalkozások súlya is (sport, művészet). A 7-8. évfolyamon a továbbtanulásban szerepet játszó tanulmányi jellegű foglalkozások aránya nőtt

A „napközis” tanulók részvételét magyarázza, hogy a felső tagozat alsóbb évfolyamain szervezett, tanulószobához és napközihez is hasonló foglalkozásokat számos iskolában napközinek nevezik. 
5. táblázat: A tanórán kívüli foglalkozások és a foglalkozásokon való részvétel a fóvárosi kerület és az M. járás intézményeiben (\%)

\begin{tabular}{lrrrrc}
\hline & Fővárosi & \multicolumn{5}{c}{ Átlag } \\
\cline { 5 - 6 } & kerület & M.járás & & 5-6. évf. & 5-6. évf. \\
\hline Sport & 28,1 & 23,1 & 24,9 & 31,9 & 19,2 \\
Tanulószoba & 6,1 & 23,6 & 17,3 & 15,6 & 18 \\
Napközi & 26,3 & 5,0 & 12,8 & 24,8 & 3 \\
Felvételi előkészítő & 20,2 & 7,5 & 12,1 & 2,8 & 20,4 \\
Szakkör & 13,2 & 10,6 & 11,5 & 15,6 & 7,8 \\
Művészeti foglalkozás & 4,4 & 16,1 & 11,8 & 15,6 & 9 \\
Egyéb & 16,7 & 7,5 & 10,9 & 8,5 & 13,2 \\
Idegen nyelv & 6,1 & 7,5 & 7,0 & 12,1 & 2,4 \\
Felzárkóztatás, fejlesztés & 6,1 & 5,5 & 5,8 & 5 & 6,6 \\
Szabadidős foglalkozás & 8,8 & 2,5 & 4,8 & 7,1 & 3 \\
Tanulmányi versenyre v. készülés & 35,3 & 4,0 & 4,5 & 5,7 & 3,6 \\
Pályaválasztás & 7,9 & 2,5 & 4,5 & 6,5 & 5,4 \\
\hline
\end{tabular}

meg egyértelmű módon (lásd 5. táblázat). Minden tanulót számításba véve, átlagosan egy tanuló 1,3 foglalkozáson vett részt, a fóvárosban 1,5, a vidéki járásban 1,2 foglalkozáson.

A tanórán kívüli foglalkozásokban való részvétel közelebbi vizsgálata során további megkülönböztetést tettünk, mivel arra voltunk kíváncsiak, hogy a tanórán kívüli foglalkozások esetében az időráfordítás, azaz a részvétel gyakorisága milyen eltérésekkel jár a tanulók percepciói, attitűdjei szempontjából. A tanórán kívüli foglalkozásokon való részvételt tekintve ennek érdekében három nagyobb csoportot különítettünk el: a gyakori résztvevőket, akik mindennap vagy majdnem mindennap részt vesznek tanórán kívüli foglalkozásokon (akik a rendelkezésre álló idő 50\%-ánál több időt töltenek tanórán kívüli tanulással), az alkalmi résztvevöket, akik hetente csak egy-két alkalommal vesznek részt ilyen foglalkozásokon (akik a rendelkezésre álló idő 50\%-ánál kevesebbet töltenek délután az iskolában), és azokat, akik egyáltalán nem vesznek részt ilyen foglalkozásokon (lásd 6 táblázat).

A tanórán kívüli foglalkozásokban összességében a válaszoló tanulók 59\%-a volt valamilyen szinten érintett, 41\%-a egyáltalán nem. Az alsóbb és a felsőbb évfolyamok között eltérés figyelhető meg a részvételben: míg az 5-6. évfolyamon a tanulók közel kétötöde vett rendszeresen részt, addig a 7-8. évfolyamon ez már csak egyötödre volt jellemző.

6. táblázat: A tanórán kívüli foglalkozásokon való részvétel évfolyamok szerint (\%)

\begin{tabular}{lccc}
\hline & 5-6. évf. (\%) & 7-8. évf. (\%) & Átlag (\%) \\
\hline Gyakori résztvevő & 38,1 & 19,9 & 28,0 \\
Alkalmi résztvevő & 25,4 & 35,6 & 31,1 \\
Nem vesz reszt & 36,4 & 44,5 & 40,9 \\
\hline
\end{tabular}

$p=0,004$ 
A tanórán kívüli átlagos részvétel az 5-6. évfolyam és a 7-8. évfolyam között 64\%-ról $56 \%$-ra csökkent. A részvétel tekintetében markáns különbség elsősorban a nemek és a vizsgált évfolyamcsoportok között volt megfigyelhető. Az évfolyamok mentén felfelé haladva mindkét nem esetében alacsonyabb a részvétel, de némileg eltérő módon: a lányok esetében a 7-8. évfolyamon az alkalmi résztvevők aránya nőtt meg, a fiúk esetében a részt nem vevők aránya alacsonyabb (52\%) (lásd 6. táblázat).

A társadalmi háttér szerinti eltérések vizsgálatát korlátozta, hogy a tanulók jelentős része nem tudta édesanyja iskolázottságát megmondani. A rendelkezésre álló válaszokból ennek ellenére kirajzolódó tendencia feltehetően közel áll a valósághoz. A mindennap bennmaradók összetétele heterogén, az egyes iskolázottsági csoportok iskolai arányát képezi le. A heti egy-két alkalommal bennmaradók között a legmagasabb arányban a felsőfokú végzettséggel rendelkező anyák gyerekei találhatóak, a részt nem vevők csoportja heterogén, de a csoportban az alacsonyabb iskolázottságú szülők gyerekei iskolai arányukhoz képest felülreprezentáltak (lásd 7. táblázat).

7. táblázat: A résztvevők összetétele az anya iskolázottsága szerint, \% (N=178)

\begin{tabular}{lcccc}
\hline & Max. szakm. (\%) & Középfok (\%) & Felsőfok (\%) & Összesen (\%) \\
\hline Gyakori résztvevő & 19,6 & 37,3 & 43,1 & 100,0 \\
Alkalmi résztvevő & 11,9 & 35,6 & 52,5 & 100,0 \\
Nem vesz reszt & 27,9 & 32,4 & 39,7 & 100,0 \\
\hline Átlag & 20,2 & 34,8 & 44,9 & 100,0 \\
\hline
\end{tabular}

$\mathrm{A} z$ egyes részvételi kategóriák jellemezhetőek az egyes foglalkozásokon való részvétellel is, azaz a foglalkozások átlagos számával és jellemzőivel is. A foglalkozások számát tekintve a két kategória közt kis eltérés figyelhető meg: a gyakori résztvevők átlagosan 2,3 foglalkozáson vettek részt, az alkalmi résztvevők 2,0 foglalkozáson. Nagyobb eltérés figyelhető meg a két csoport között az egyes foglalkozások szempontjából. A gyakori résztvevők az átlagnál magasabb arányban járnak napközis és tanulószobai foglalkozásokra, de sport, szakkör és szabadidős, ill. müvészeti foglalkozás is gyakori. Az alkalmi

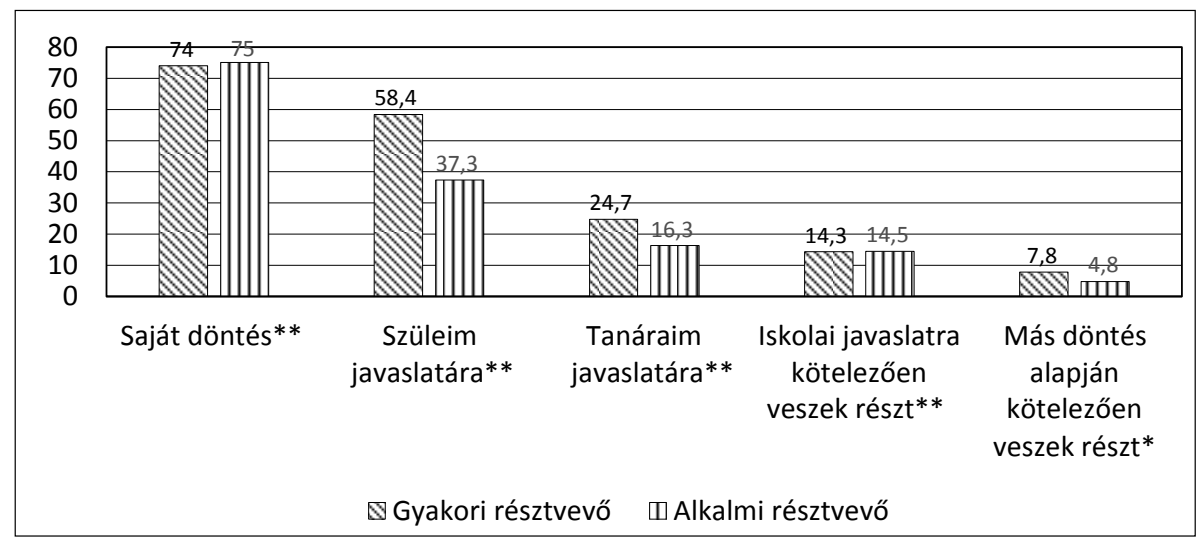

3. ábra: A tanórán kívüli részvételről való döntésben részt vevők (átlag $\%$-ban). ${ }^{*} p<0,05,{ }^{* *} p<0,01$ 
résztvevők esetében alacsonyabb a tanulószobások aránya, jelentős a sport, a szakkör, illetve a felvételi előkészítő foglakozásokon való részvétel.

Fontos kérdés a tanórán kívüli foglalkozások esetében a részvételhez vezető döntés, ami a foglalkozások kedveltségét, eredményességét is befolyásolhatja. A tanulók válaszai alapján a tanórán kívüli foglalkozásokon való részvétel a legnagyobb arányban mind a gyakori, mind az alkalmi résztvevők esetében a tanulók saját döntésén múlt. A gyakori résztvevők esetében leginkább jellemző a saját döntés volt, emellett szerepet játszott a mások általi javaslat. Az alkalmi résztvevők esetében a saját döntés szerepe az előbbihez hasonló volt, s valamivel kevesebb más befolyásoló szereplő állt a háttérben (lásd 3. ábra).

Megkértük a tanórán kívüli foglalkozásokban érintett, kérdőívre válaszoló tanulókat, hogy értékeljék, mennyire kedvelik azokat a foglalkozásokat, amelyekre járnak. A tanulók értékelése a várakozásnak megfelelően azt mutatta, hogy a gyakori résztvevők általánosságban jobban kedvelték azokat a tanórán kívüli foglalkozásokat, amelyekre jártak, mint az alkalmi résztvevők (lásd 4. ábra).

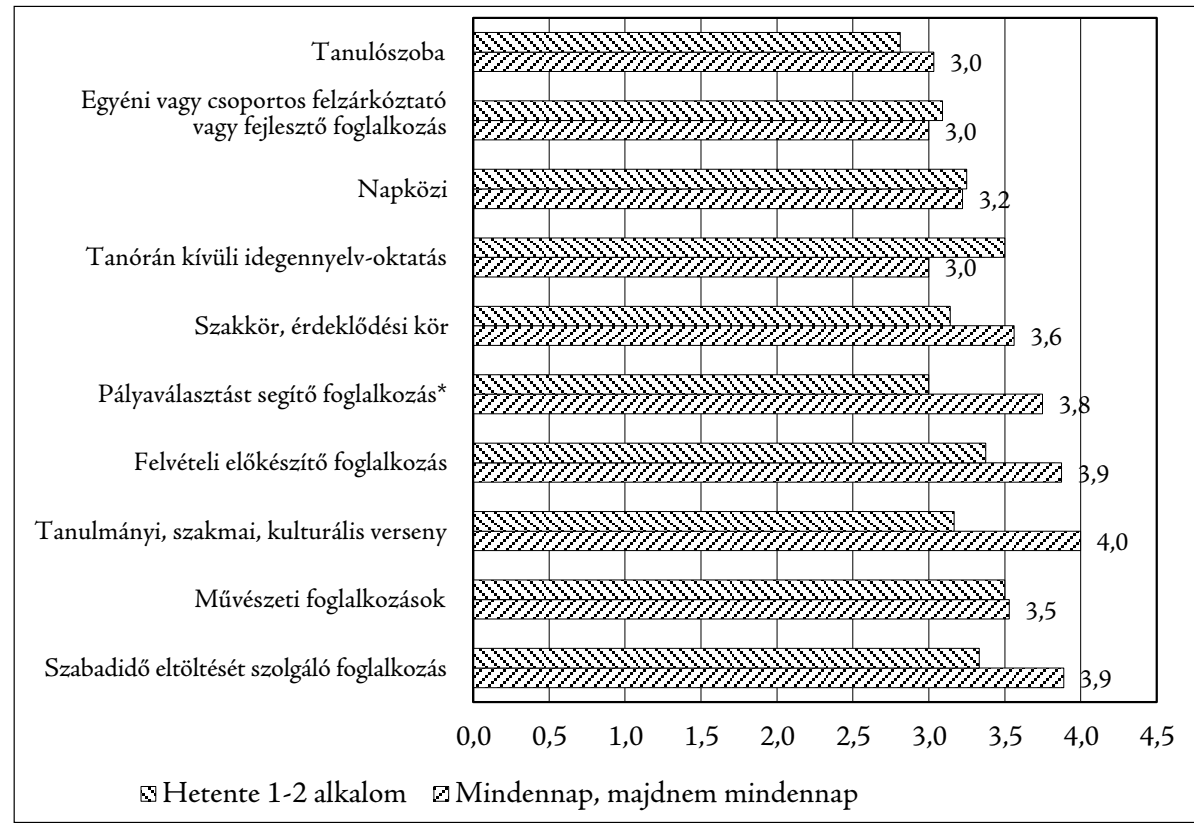

4. ábraः A tanórán kívüli foglalkozások kedvelése a részvétel gyakorisága szerint (1-4 skála átlagértékei). ${ }^{*} p<0,05$

\section{Iskolán kívüli foglalkozások és részvétel}

A kutatás lehetőséget adott arra is, hogy figyelemmel kísérjük az általunk vizsgált iskolák esetében az iskolán kívüli részvétel alakulását. Adataink azt mutatják, hogy három általános iskola szintjén a lehetőségek részben hasonlóak a tanórán kívüli és az iskolán kívüli foglalkozások vonatkozásában, s hasonló, tanulmányi téren tehetséggondozást és felzárkóztatást kínáló foglalkozások mellett nem tanulmányi jellegű, gazdagító foglalkozásokra jártak a tanulók mindkét tanulási környezetben. Nem volt ugyanakkor megfi- 


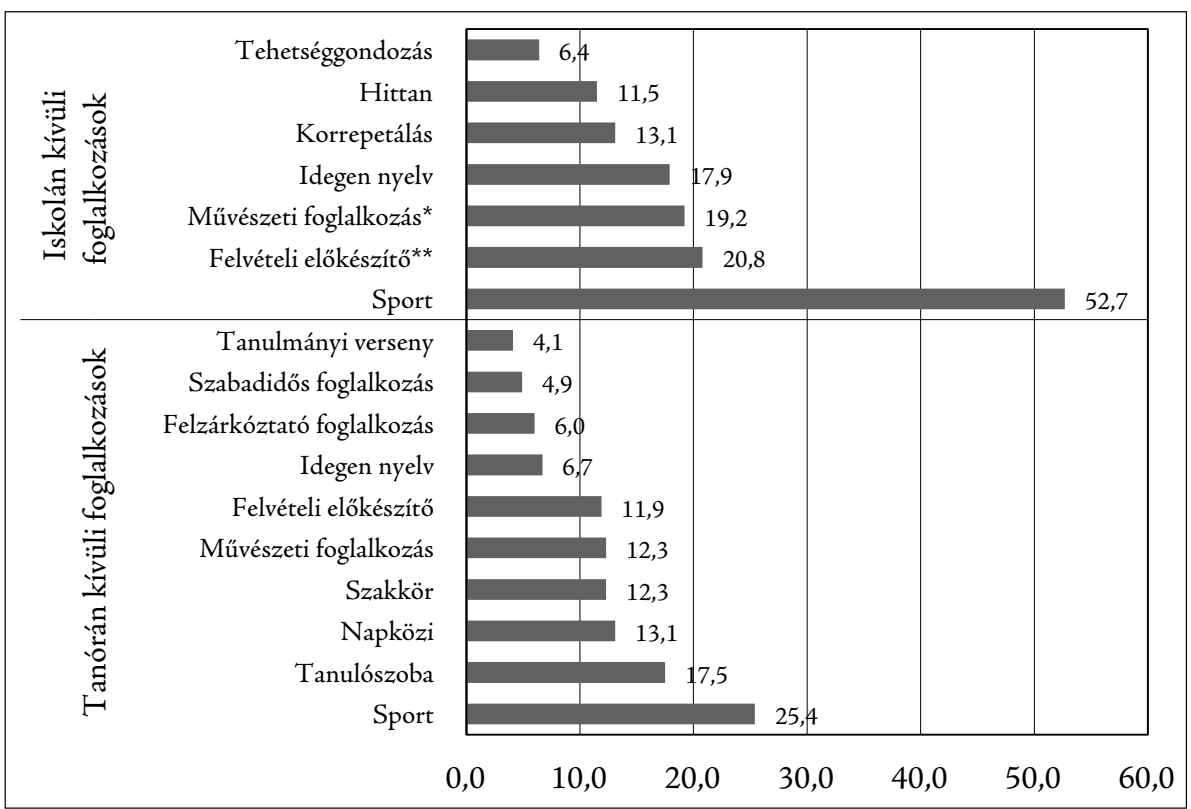

5. ábra: A tanórán kívüli és iskolán kívüli foglalkozásokon részt vevő tanulók aránya, átlag (\%).

$$
{ }^{*} p<0,05,{ }^{* *} p<0,01
$$

gyelhető hasonló párhuzamos részvétel a gondoskodó típusú foglalkozások kapcsán. Az iskolán kívüli foglalkozásokon való részvétel tendenciái sok hasonlóságot mutattak az iskolai szervezésü tanórán kívüli foglalkozásokon való részvétellel: a leggyakoribb iskolán kívüli elfoglaltságnak itt is a sport bizonyult, ezt követte a felvételi előkészítő, a művészeti foglalkozás és az idegen nyelv. Összességében az iskolán kívüli foglalkozásokon való részvétel a három vizsgált iskola tanulóinak átlagában hasonlóan alakult az iskolán belüli délutáni részvételhez, a tanulók 62\%-át érintette ${ }^{6}$ (lásd 5. ábra). Figyelemre érdemes továbbá, hogy az iskolán kívüli foglalkozások szempontjából gyakori résztvevőnek számító tanulók az iskolán kívül is magasabb számú foglalkozásban bizonyultak érintettnek: a gyakori résztvevők átlagosan 1,8 az alkalmi résztvevők 1,2 iskolán kívüli foglalkozáson vettek részt.

Mivel a kérdőívre válaszoló tanulók kérésünkre értékelték azoknak a foglalkozásoknak a kedveltségét, amelyekre jártak, ez lehetőséget adott a két szektor foglalkozásainak tanulói nézőpontú összehasonlítására is. Az iskolán kívüli foglalkozásokat a tanórán kívüli foglalkozásoknál valamivel jobban kedvelték az érintett tanulók, de a részvételhez hasonló mértékű eltérés a tanulók kedveltségi értékelésében nem tükröződik. A tanulók a hasonló foglalkozásokat a két szektorban hasonlóan értékelték, a kedvelés értékei úgy tünik, nem elsősorban a szektor, hanem inkább a foglalkozások típusa szerint tértek el egymástól a gazdagító (pl. sport, müvészet) és tehetséggondozó foglalkozások a legkedveltebbek: a lemaradást megelőző tanulmányi foglalkozásokat kedvelték kevésbé a tanulók, függetlenül attól, hogy milyen szervezésben működtek (lásd 6. ábra).

A $z$ országos átlagtól jelentős mértékben eltérő adatokhoz nagymértékben hozzájárulhatott a kedvezőbb tanulói összetételű iskolák esetében megfigyelhető magasabb válaszadási arány. 


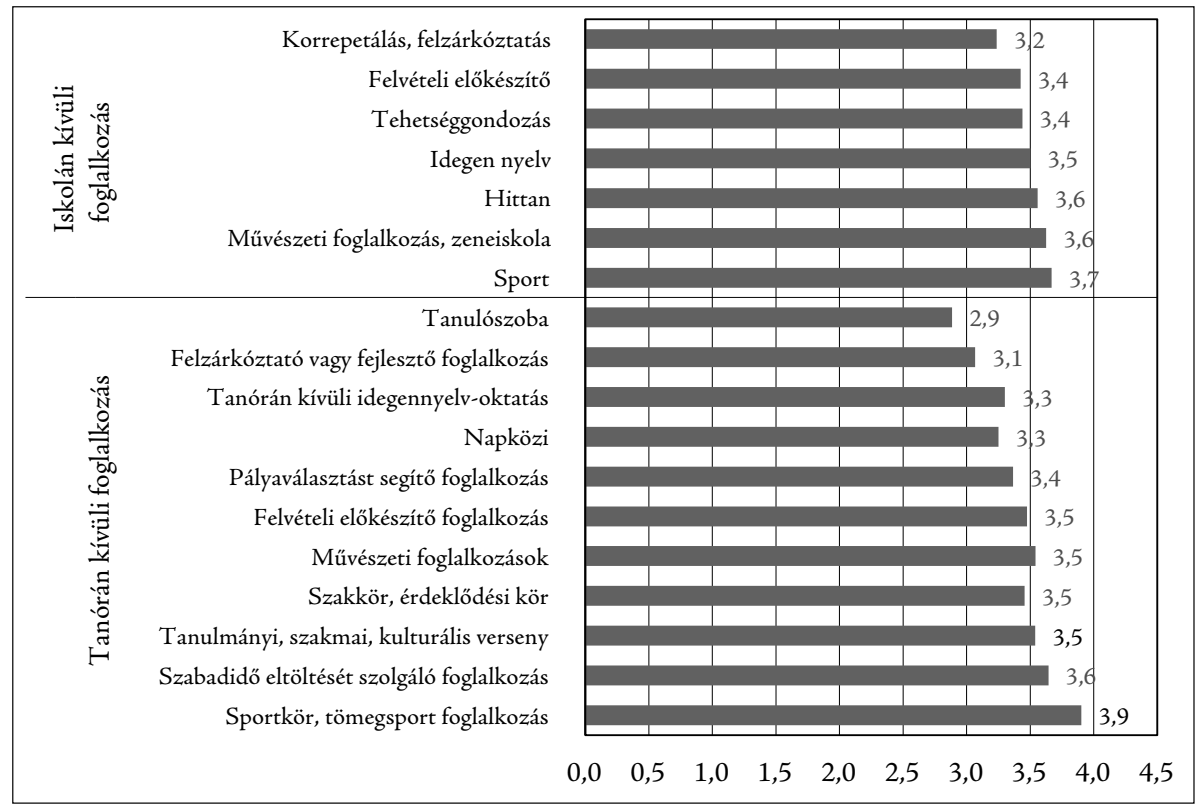

6. ábra: A tanórán és iskolán kívüli foglalkozások kedvelése (1- 4 skála átlagai)

\section{A tanórán kívüli tanulásban résztvevők nézetei, attitüdjei}

A tanórán kívüli tanulásban való részvételi gyakoriság hatását is igyekeztünk megismerni a tanulás, illetve az iskola viszonylatában. A kérdést nem közvetlenül a tanulás eredményein, osztályzatokon vagy kognitív kompetenciákon igyekeztünk mérni, hanem elsősorban a tanulók nézetein, percepcióin.

\section{A tanulással kapcsolatos nézetek}

A tanulással kapcsolatos nézetek eltéréseinek feltárása érdekében néhány állítással igyekeztünk körüljárni a kérdést. A kérdésfeltevésünk négy, átfogó módon megfogalmazott kétpólusú állításhoz kapcsolódott, s azt kértük a válaszadó tanulóktól, hogy jelezzék, hogy a lehetséges válaszok melyik pólusával értenek teljesen vagy inkább egyet, vagy esetleg nem tudják eldönteni. A négy állítás a tanulás hasznosságára (hasznos - nem hasznos), intézményi kereteire (iskolai - nem csak iskolai), társas környezetére (egyéni-társas tevékenység) és motiváló erejére (fáradságos-érdekes) irányult. Az állításpárokban a másodikként megfogalmazott állítás tartalmazta a tanulással összefüggésben inkább pozitív és a tanulás tágabb értelmezéséhez kapcsolódó állításokat. Az adatokat elemezve kitűnik, hogy a tanulók az állítások közül leginkább azzal értettek egyet, hogy a tanulás hasznos (56\%). Nehezebbnek bizonyult annak eldöntése, hogy a tanulás iskolai vagy nem csak iskolai tevékenység, a mérleg egy kevéssel a második állítás irányába billent (39,5\%). Hasonló volt a helyzet a tevékenység egyedüli vagy társas lehetőségeket is tartalmazó sajátosságának megítélésénél (35,3\%). Az utolsó állítás esetében a mérleg az ellenkező oldalra billent: a tanulást a tanulók többsége inkább fáradságos tevékenységnek 
8. táblázat: A tanulással kapcsolatos vélemény, egyetértők \%-a

\begin{tabular}{lcccc}
\hline & $\begin{array}{c}\text { Egyedül végzett- } \\
\text { sok társas } \\
\text { lehetőség }\end{array}$ & $\begin{array}{c}\text { Nem hasznos } \\
\text { - hasznos }\end{array}$ & $\begin{array}{c}\text { Iskolai tevékenység - } \\
\text { nem csak iskolai tevé- } \\
\text { kenység }\end{array}$ & $\begin{array}{c}\text { Fáradságos } \\
\text { - érdekes }\end{array}$ \\
\hline $\begin{array}{l}\text { Az első állítással } \\
\text { értek egyet }\end{array}$ & 32,9 & 21,1 & 36,1 & 37,1 \\
$\begin{array}{l}\text { Nem tudja } \\
\text { A második állítás- } \\
\text { sal értek egyet }\end{array}$ & 31,8 & 22,8 & 24,5 & 31,4 \\
\hline
\end{tabular}

A feltett kérdés: Mit jelent számodra a tanulás? Melyik állítással értesz inkább egyet az alábbiak közül?

tapasztalta (37\%), bár nem volt kevés azok aránya sem, akik érdekesnek találták (31,4\%) (lásd 8. táblázat).

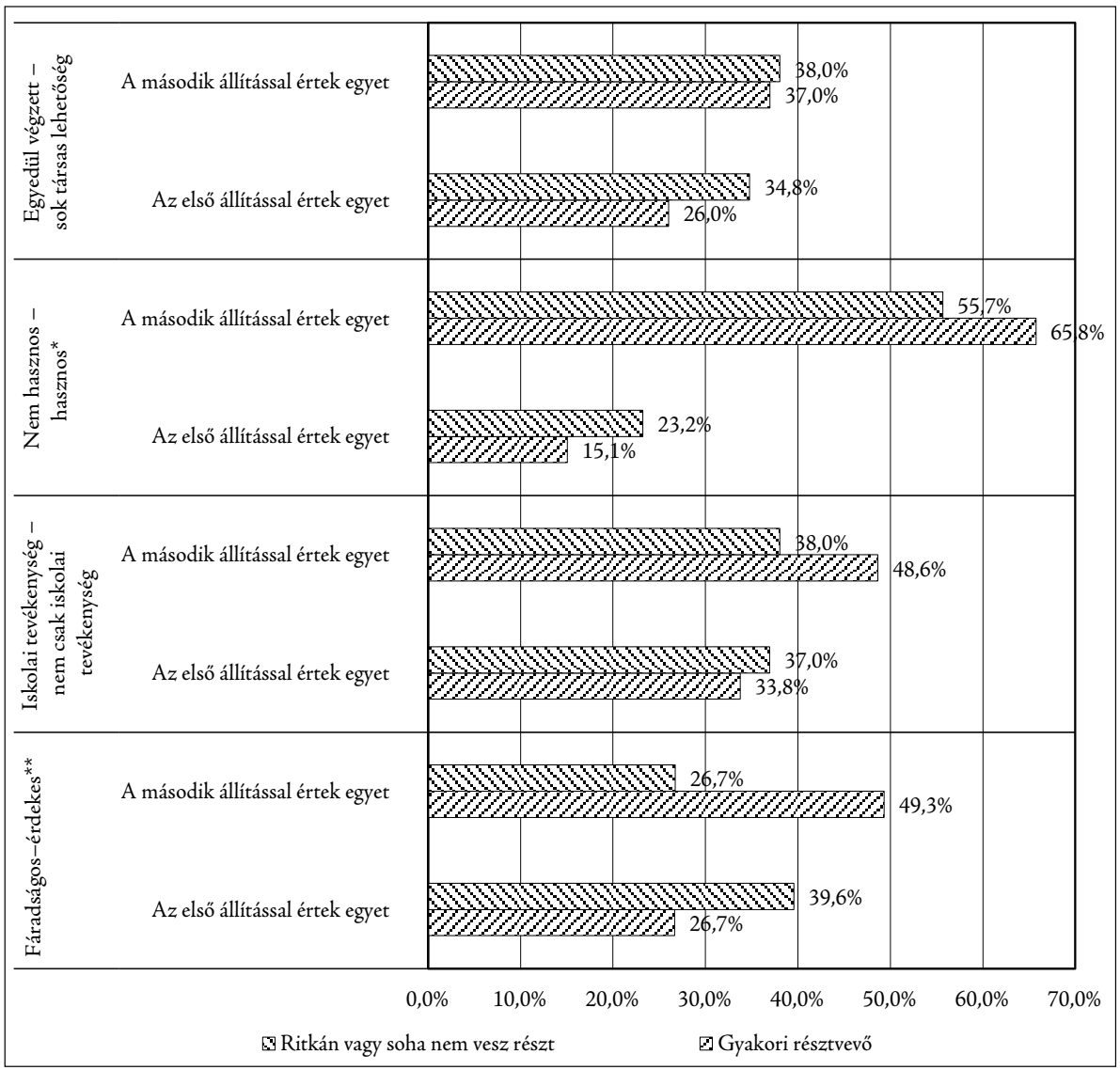

7. ábra: Az állításokkal való egyetértés a délutáni foglalkozásokon való részvétellel összefüggésben (\%) ${ }^{*} p<0,05,{ }^{* *} p<0,01$ 
A következő lépésben a délutáni részvétel gyakorisága függvényében vizsgáltuk az eltérést, a tanórán kívüli foglalkozásokon való részvétel gyakorisága szerint. A négy állításpár közül három esetében a délutáni foglalkozásokban jobban érintett tanulók a második állítás mellett döntöttek nagyobb arányban. A döntés legegyértelmübb a tanulás érdekességére irányuló kérdés esetében volt (49,3\%-26,7\%). A másik két állításpár (iskolai tevékenység, ill. hasznosság - nem csak iskolai tevékenység) esetében az eltérés kisebb volt a két csoport között. A negyedik állításpár (a tanulás egyedüli vagy társas tevékenység) esetében a két csoport véleménye közelebb esett a társas értelmezéshez és egymáshoz is (37\%, 38\%), ugyanakkor számottevő maradt az eltérés az első, a tanulást egyedüli tevékenységként értelmező állítás esetében (26\%, 34,8\%) (lásd 7. ábra).

Az eltérések arra engednek következtetni, hogy a tanórán kívüli tanulási részvételben nagyobb mértékben érintettek - eltérő tapasztalatok birtokában - eltérően ítélik meg a tanulást: valamivel tágabban értelmezik, a hagyományos tanulási környezettől jobban el tudnak tekinteni és pozitívabban látják a hasznosság, de különösen az érdeklődés szempontjából nézve. A legnagyobb mértékű, a tanórán kívüli részvétel gyakoriságától függő eltérés (22\%) a belső motiváltsághoz kapcsolódó állítás esetében volt megfigyelhető.

\section{Az iskolához és a tanuláshoz való viszony}

$\mathrm{A} z$ iskolához való viszony elemzése során több kérdés vizsgálatára került sor. Vizsgáltuk a kérdést önmagában és egyes iskolai tevékenységekhez kapcsolható percepciók elemzésén keresztül keresztül, a részvétel függvényében is. Első lépésben azt vizsgáltuk, hogy hogyan alakulnak a tanulók iskolával kapcsolatos nézetei a tanórán kívüli foglalkozások-

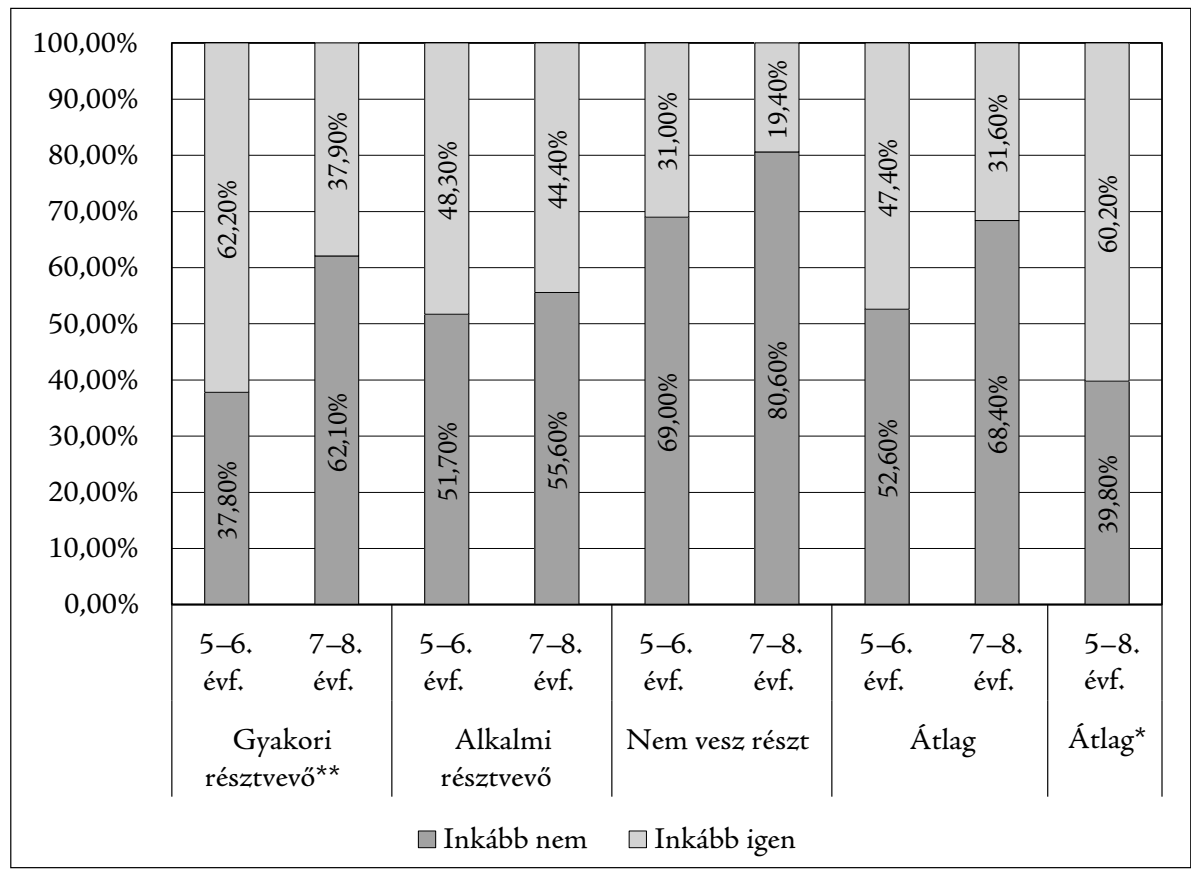

8. ábra: Szeretsz-e iskolába járni? Tanulói válaszok (\%). ${ }^{*} p<0,05,{ }^{* *} p<0,01$ 
ban való érintettség figyelembevételével a felső tagozat első és második felében. A felső tagozatos tanulók átlagosan 39\%-ban válaszolták, hogy inkább szeretnek, és 61\%-ban, hogy inkább nem szeretnek iskolába járni. A z 5-6. évfolyamon az iskolába járást szeretők aránya kedvezőbben alakult (47-53\%), 7-8. évfolyamra azonban kisebbségbe kerültek, s többségbe kerültek az iskolát nem szeretők (31-69\%). A tanórán kívüli foglalkozásokon való részvétel figyelembevételével valamivel derűsebb a kép: a gyakori résztvevők körében többen nyilatkoztak úgy, hogy szeretik az iskolába járást (lásd 8. ábra).

$\mathrm{A} z$ iskolához való viszony, az iskolai tevékenységek megítélése megközelíthető más módon, a tanítási órák kedvelésén, a tanulnivaló megítélésén, a tanár-diák kapcsolaton keresztül is. Egy állítássor segítségével e részletekhez is közelebb tudtunk jutni. Az állításokkal való egyetértésre kérve a tanulókat egy átlagos fontossági sorrend vált megragadhatóvá. A felső tagozaton a tanulók körében a legnagyobb átlagos egyetértés a tanórán kívüli foglalkozásokhoz kapcsolódó állítással volt, ezt követően azzal az állítással értettek egyet a tanulók, hogy új és érdekes dolgokat tanulnak a tanórákon. A véleményekben a legnagyobb eltérés elsősorban a gyakori résztvevők, valamint az alkalmi résztvevők és a részt nem vevők között húzódott (lásd 9. táblázat).

9. táblázat: Tanulói percepciók részvételi típusok szerint (1-5 skála átlagai)

\begin{tabular}{|c|c|c|c|c|c|c|c|}
\hline & 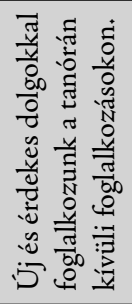 & 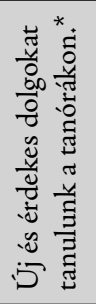 & 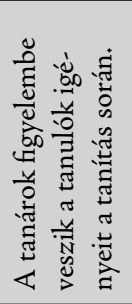 & 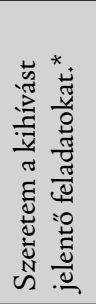 & 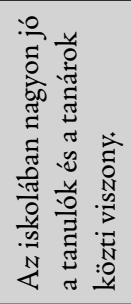 & 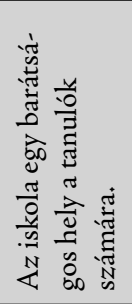 & 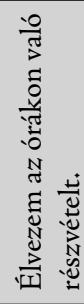 \\
\hline $\begin{array}{l}\text { Gyakori } \\
\text { résztvevő }\end{array}$ & 4,06 & 4,06 & 3,75 & 3,80 & 3,66 & 3,58 & 3,51 \\
\hline $\begin{array}{l}\text { Alkalmi } \\
\text { résztvevő }\end{array}$ & 3,70 & 3,66 & 3,36 & 3,29 & 3,24 & 3,21 & 3,12 \\
\hline $\begin{array}{l}\text { Nem vesz } \\
\text { reszt }\end{array}$ & 3,85 & 3,51 & 3,37 & 3,26 & 3,35 & 3,18 & 3,16 \\
\hline Átlag & 3,87 & 3,72 & 3,48 & 3,43 & 3,41 & 3,31 & 3,26 \\
\hline
\end{tabular}

A feltett kérdés: Milyen mértékben értesz egyet az alábbiakkal? ${ }^{*} p<0,05$

$\mathrm{A} z$ adatokat évfolyamok szerint megbontva eltérő tendenciák ragadhatóak meg az alsóbb és a felsőbb évfolyamokon. A tanulók az 5-6. évfolyam átlagát tekintve a legnagyobb mértékben azzal az állítással értettek egyet, hogy új és érdekes dolgokkal foglalkoznak a tanórán kívüli foglalkozásokon, alacsonyabb pontszámon értettek egyet a tanóra hasonló megítélésével. Az átlagot tekintve 4-es alatti átlagot ért el a tanár-diák viszony, a tanulók igényeinek figyelembevétele és a kihívást jelentő feladatokkal kapcsolatos állítás értékelése. A legalacsonyabb átlagpontokat az órák élvezete és az iskola kapta. A tanórán kívüli részvétel típusait figyelembe vevő felbontás differenciáltabb képet mutat: a gyakori tanórán kívüli részvétellel jellemezhető csoport egy kivétellel valamennyi esetben kedve- 
10. táblázat: Tanulói percepciók az 5-6. évfolyamon, részvételi típusok szerint (1-5 skála átlagai)

\begin{tabular}{|c|c|c|c|c|c|c|c|}
\hline & 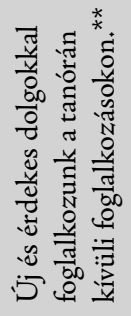 & 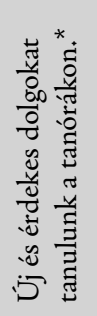 & 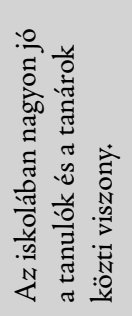 & 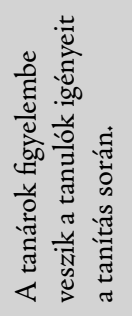 & 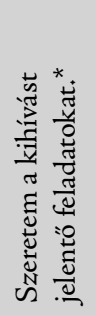 & 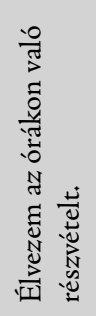 & 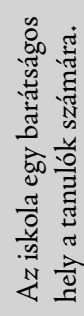 \\
\hline Gyakori résztvevő & 4,16 & 4,23 & 3,98 & 4,09 & 3,95 & 3,72 & 3,7 \\
\hline Alkalmi résztvevő & 4,30 & 3,96 & 3,54 & 3,52 & 3,55 & 3,52 & 3,4 \\
\hline Nem vesz reszt & 4,13 & 3,87 & 3,75 & 3,55 & 3,67 & 3,53 & 3,3 \\
\hline Átlag & 4,18 & 4,04 & 3,79 & 3,76 & 3,75 & 3,60 & 3,5 \\
\hline
\end{tabular}

A feltett kérdés: Milyen mértékben értesz egyet az alábbiakkal? ${ }^{*} p<0,05,{ }^{* *} p<0,01$

zőbben ítélte meg a helyzetet. A tanórán kívüli foglalkozásokat leginkább kedvelőknek ugyanakkor nem ők, hanem az alkalmi résztvevők bizonyultak (lásd 10. táblázat).

A 7-8. évfolyamon kevésbé kedvezővé vált az általános kép: 4-es értéknél alacsonyabbnak bizonyult az összes állítással való átlagos egyetértés. A sorrend élén ugyan a tanórán kívüli foglalkozásokkal kapcsolatos állítás található, de a korábbinál jóval alacsonyabbra értékelve $(3,6)$, ezt követte a tanórára vonatkozó állítás $(3,5)$. A sorrendben elfoglalt helyzet két foglalkozás esetében jelentős mértékben megváltozott: a tanár-diák viszony $(3,1)$ és az „élvezem a tanórákon való részvételt” $(2,9)$ állítás a sor utolsó előtti és utolsó helyére került. A helyzetet a legkedvezőbbnek ez esetben a tanórán kívüli foglalkozások gyakori résztvevői látták (lásd 11. táblázat).

11. táblázat: Tanulói percepciók a 7-8. évfolyamon, részvételi típusok szerint (1-5 skála átlagai)

\begin{tabular}{|c|c|c|c|c|c|c|c|}
\hline & 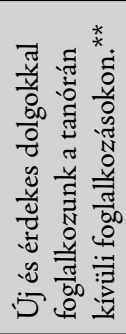 & 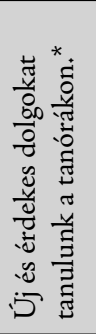 & 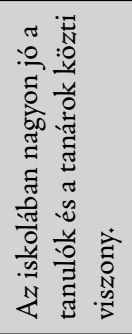 & 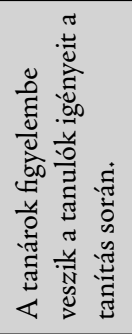 & 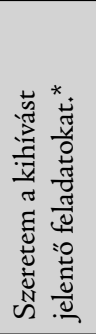 & 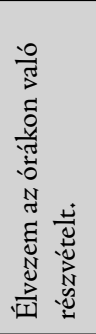 & 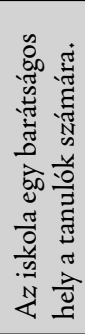 \\
\hline Gyakori résztvevő & 3,89 & 3,89 & 3,26 & 3,76 & 3,67 & 3,29 & 3,46 \\
\hline Alkalmi résztvevő & 3,35 & 3,55 & 3,12 & 3,33 & 3,21 & 2,95 & 3,14 \\
\hline Nem vesz reszt & 3,68 & 3,30 & 3,10 & 3,26 & 3,02 & 2,92 & 3,08 \\
\hline Átlag & 3,63 & 3,50 & 3,14 & 3,29 & 3,21 & 3,01 & 3,18 \\
\hline
\end{tabular}

A feltett kérdés: Milyen mértékben értesz egyet az alábbiakkal? ${ }^{*} p<0,05,{ }^{* *} p<0,01$ 


\section{A tanulásra forditott idö, preferenciák}

$\mathrm{A} z$ elemzés végén érdemes kitérni két olyan kérdésre is, ami a három tanulási környezetet összevethetővé teszi: az időráfordítás és a preferenciák kérdésére. A tanulókat megkértük, adják meg egy átlagos napra, hogy mennyi időt töltöttek egyes, tanulással összefüggő tevékenységekkel, ill. foglalkozásokon. A tanulók az adott napon átlagosan legtöbb időt, közel 6 (60 perces) órát a tanórai tanulással töltöttek, s szintén jelentős volt az otthoni tanulásra fordított 1-1,5 órás időtartam is. A tanórán kívüli tanulásra fordított idő 0,6-1,1 óra között alakult, a különóra 1 óránál kevesebb, 0,6-0,7 óra körüli időt vett igénybe. $\mathrm{A} z$ adott napon 8 és 9 óra között alakult a tanulással töltött összes idő az általunk vizsgált tanulók esetében.

A tanulók közt a tanórán kívüli foglalkozásokban jobban érintett, gyakori résztvevők töltötték a tanórán kívüli tanulással a legtöbb időt, és ők voltak azok is, akik a legtöbb időt töltötték különórákkal is. Az alkalmi résztvevők szintén sok időt töltöttek mindkét tanulási formával, de otthoni tanulással is, s összességében ők töltöttek legtöbb időt tanulással. A tanórán kívüli tanulási formában részt nem vevők esetében volt a legkisebb a tanulásra fordított idő (lásd 12. táblázat).

12. táblázat: A tanulásra fordított idő tanórán kívüli részvétel és évfolyam szerint* (óra)

\begin{tabular}{lccccc}
\hline & $\begin{array}{c}\text { Tanórák azz } \\
\text { iskolában }\end{array}$ & $\begin{array}{c}\text { Tanórán kívüli ta- } \\
\text { nulás iskolában** }\end{array}$ & $\begin{array}{c}\text { Különóra, } \\
\text { iskolán kívül }\end{array}$ & $\begin{array}{c}\text { Tanulás, házi feladat } \\
\text { elkészítése otthon }\end{array}$ & $\begin{array}{c}\text { Napi tanulási } \\
\text { idö összesen }\end{array}$ \\
\hline $\begin{array}{l}\text { Gyakori } \\
\text { résztvevő }\end{array}$ & 5,75 & 1,12 & 0,68 & 1,20 & 8,74 \\
$\begin{array}{l}\text { Alkalmi } \\
\text { résztvevő }\end{array}$ & 6,00 & 0,89 & 0,59 & 1,48 & 8,96 \\
$\begin{array}{l}\text { Nem vesz } \\
\text { reszt }\end{array}$ & 5,77 & 0,64 & 0,57 & 1,36 & 8,34 \\
\hline
\end{tabular}

A feltett kérdés: Mennyi időt töltöttél az alábbiakkal a legutolsó csütörtökön?

*A saját bevallásra épülő adatok helyenként ellentmondásosak, tendenciájukra érdemes figyelni. ${ }^{* *} p<0,05$

Az időráfordítás kérdéséhez kapcsolódóan az egyes tevékenységek kedveltségére is rákérdeztünk. Az átlagos kedveltségi sorrend élén a családi együttlét állt, hasonló a barátokkal való együttlét, ezt a számítógéphez kapcsolódó tevékenységek követik. A tanulással összefüggő első tevékenység, az iskolán kívüli különóra a kedveltségi sorrend negyedik helyén jeleik meg, ezt követi a tanóra, csak ezután következik az iskolán kívüli tanulás. A $z$ utolsó helyre a tanulás és a házi feladat otthoni elkészítése került.

A kedveltségi adatok évfolyamok mentén felbontott vizsgálata egy átrendeződést is érzékeltet az 5-6. és a 7-8. évfolyamok között. Míg az 5-6. évfolyamon a házi feladat kivételével valamennyi tanulással összefüggő tevékenységet 3-as érték felett értékelték a tanulók, addig a 7-8. évfolyamon már csak az iskolán kívüli különórákat. Az 5-6. évfolyamon a tanulás - a család és a barátok után - a harmadik helyen a különóra formájában jelenik meg legelőbb, megelőzve a számítógéphez és TV-hez kapcsolódó időtöltést, a különórát a tanórán kívüli foglalkozások követték, megelőzve a tanórai foglalkozásokat. A 7-8, évfolyamon a sorrend is átrendeződött, a sorrendben a tanulási tevékenységek a korábbiakhoz képest alacsonyabb értéken jelentek meg, az ezen belüli sorrend élén az iskolán kívüli 
13. táblázat: Az egyes tevékenységek kedvelése (1-4 skála)

\begin{tabular}{|c|c|c|c|c|c|c|c|c|}
\hline & 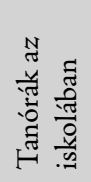 & 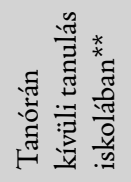 & 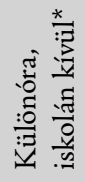 & 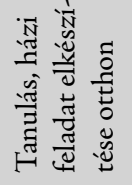 & 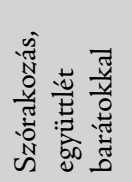 & 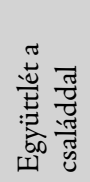 & P & 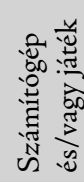 \\
\hline 5-6. évf. & 3,00 & 3,08 & 3,66 & 2,63 & 3,79 & 3,91 & 3,36 & 3,52 \\
\hline 7-8. évf. & 2,79 & 2,49 & 3,27 & 2,52 & 3,83 & 3,76 & 3,32 & 3,53 \\
\hline Átlag & 2,88 & 2,76 & 3,47 & 2,57 & 3,81 & 3,83 & 3,34 & 3,52 \\
\hline
\end{tabular}

${ }^{*} p<0,05,{ }^{* *} p<0,01$

különóra állt, ezt követte a tanóra, a tanórán kívüli foglalkozások és végül a házi feladat (lásd 13. táblázat). Az adatok látni engedik, hogy az általános iskola felső tagozatára járó tanulók világában megindult egy fontos változás, s a kortárskapcsolatok előtérbe kerülésével a korábban kedvelt foglalkozások is könnyen átértékelődnek.

\section{Összegzés}

Elemzésünkben a tanórán és iskolán kívüli tanulás néhány tapasztalatát vizsgáltuk a tanulás lehetőségeinek oldaláról három tanulási környezettel kapcsolatosan, három általános iskola tanulóinak kérdőíves adatai segítségével. Az elemzésben tanórai, tanórán kívüli és iskolán kívüli tanulási környezetekkel kapcsolatos tapasztalatot a tanulói részvétel oldaláról vizsgáltunk. Kutatásunkban három általános iskola felső tagozatos tanulói körében a tanórai munkában 83\%-os, a tanórán kívüli foglalkozásokban közel 60\%-os érintettséget találtunk a tanórán kívüli tanulással összefüggésben, s hasonló nagyságrendű volt az iskolán kívüli tanulásban való részvétel is a tanulói válaszok alapján. A tanórán kívüli és iskolán kívüli foglalkozásokon való részvétel láthatóan eltér a felső tagozat elején és végén: az alsóbb évfolyamokon a gazdagító, a felsőbbeken már jelentős részben a továbbtanulással kapcsolatos kérdésekhez igazodva formálódik.

A tanulói vélemények nézőpontjából a három tanulási környezet megítélése eltért egymástól, az eltérést láthatóan az évfolyamok, azaz a tanulók életkora, valamint a részvétel is befolyásolja. A tanórai tanulással kapcsolatban a tanulói véleményekben a kedvelt tevékenységek mellett megjelentek kevésbé kedvelt tevékenységek is, a magasabb évfolyamokon az utóbbiakat magasabb arányúnak érzékelték a tanulók. A tanórán és az iskolán kívüli tanulást egyaránt kedvelik a tanulók, a foglalkozások megítélése közel esett egymáshoz, de az iskolán kívüli lehetőségeket valamivel jobbnak ítélték. Az iskolán kívüli tanulás a középiskolai továbbtanulás közeledtével előtérbe kerül, s a részvétel és a kedvelés vonatkozásában a tanórán kívüli tanulásnál tartósabbnak bizonyul.

A tanórán kívüli részvétel gyakoriságával összefüggésben vizsgálva a tanulással kapcsolatos nézetek alakulását, ezek a gyakori résztvevők, azaz a tanórán kívüli foglalkozásokkal több időt töltő tanulók esetében bizonyultak pozitívabbnak. A magasabb részvételi arány általánosságban kedvezőbb tanuláshoz és iskolához való viszonynyal is függ össze: a magasabb tanórán kívüli részvételi arány általánosságban a tanulói percepciók vonatkozásában pozitívabb tanulással és iskolai tevékenységekkel összefüggő tapasztalatokat és beállítódást mutat. A tanórán kívüli részvétel kedvező hatása fel- 
tehetőleg összefügg a nagyobbrészt önkéntes részvétellel, az erősebb bevonódással és a tanóraitól eltérő foglalkozásokkal, továbbá a társas tanulási környezettel, amelyben megvalósul.

A tanulásra fordított idő a három tanulási környezetet egyaránt figyelembe véve a tanórai tanulás esetében volt a legjelentősebb, a tanulói preferenciák oldaláról nézve azonban a tanóra a sor végére került. A tanórai, tanórán kívüli és az iskolán kívüli tanulás a vizsgált iskolák tanulóinak több mint fele esetében nem zárja ki egymást, láthatóan tartósan 'elférnek' egymás mellett. A vizsgálatban érintett általános iskolai tanulók jelentős része a tanórai és tanórán kívüli foglalkozások mellett az iskolán kívüli tanulásban is számottevő arányban részt vett. A tanulói részvétel lehetősége a három tanulási környezetben részben kiegészíti egymást, részben egymással versenyhelyzetben történik.

\section{IRODALOM}

Cefai, C., Bartolo, P. A., Cavioni, V. \& Downea, P. (2018) Strenghtening Social and Emotional Education as a Core Curricular Area across the EU. A Review of the International Evidence. Analytical Report. European Union.

Covay, E. \& Carbnaro, W. (2010) After the Bell: Participation in Extracurricular Activities, Classroom Behaviour and Academic Achievement. Sociology of Education, Vol. 83. No. 1. pp. 3-22.

Eccles, J. (2005) The Present and Future of Research on Activity Settings as Developmental Contexts. In: Mahoney et al. (eds) Organized Activities as Conexts of Development. Extracurricular Activities, After-school and Community Programs. New Jersey, Psychology Press, Lawrence Earlbaum Associates, Inc. pp. 353-371.

Feldman, A, F. \& Matjasko, J. L. (2005) The Role of School-based Extracurricular Activities in Adolescent Development: A Comparative Review and Future Directions. Review of Educational Research, Vol. 75. No. 2.pp. 159-210.

Finn, J. (1989) Withdrawing from School. Review of Educational Research, Vol. 59. No. 1. pp. 123-147.

Halász G. (2009) Tanulás, tanuláskutatás és oktatáspolitika. Pedagógusképzés, Vol. 7. No. 2-3. pp. 7-36.

Huang, D. (2013) Building Resiliency for American At-Risk Youth During Afterschool Hours: The Importance of Dosage and Implementation Quality on Youth Outcomes. In: J. Eccarius, E. Klieme, L. Stecher \& J. Woods (eds) Extended Education - an International Perspective. Proceedings of the International Conference on Extracurricular and Out-of-School Timre Educational Research. Opladen, Berlin, Toronto, Verlag Barbara Budrich, Barbara Budrich Publishers. pp. 147-174.

Imre A. (2015, ed.) Eredményesség és társadalmi beágyazottság. Budapest, Oktatáskutató és Fejlesztő Intézet.

Józsa K., D. Molnár É. \& Zsolnai A. (2020) Az iskola affektív és szociális jelenségvilágának kutatása. Magyar Tudomány, Vol. 181. No. 1. pp. 47-55.

LLLP (2019) 21st Century Learning Environments. LLLP position paper. http://1llplatform. eu/1ll/wp-content/uploads/2019/10/LLLP-Position-paper-21CLE.pdf [Letöltve: 2020. 07. 26.]

Mahoney J. L., Larson R. W., Eccles, J. S. \& Lord, H. (2005) Organized Activities as Developmentel Contexts for Children and Adolescents. In: Mahoney et AL. (eds) 
Organized Activities as Conexts of Development. Extrecurricular Activities, After-school and Community Programs. Lawrence Earlbaum Associates, Inc. pp. 5-22.

Miller, B. (2003) Critical Hours. Afterschol Programs and Educational Success. Nellie Mae Educational Foundation. pp. 1-125.

OECD (2015) Skills for Social Progress. The Power of Social and Emotional Learning. https://nicspaull.files.wordpress.com/2017/03/oecd-2015-skills-for-social-progresssocial-emotional-skills.pdf [Letöltve: 2020. 07. 26.]

Skinner, E. \& Pitzer, J. R. (2013) Development Dynamics of Student Engagement, Coping and Everyday Resilience. In: Christenson et Al. (eds) Handbook of Research on Student Engagement. Springer. pp. 21-44.

A cikk a Creative Commons Attribution 4.0 International License (https://creativecommons.org/licenses/ by/4.0/) feltételei szerint publikált Open Access közlemény, melynek szellemében a cikk bármilyen médiumban szabadon felhasználható, megosztható és újraközölhető, feltéve, hogy az eredeti szerző és a közlés helye, illetve a CC License linkje és az esetlegesen végrehajtott módosítások feltüntetésre kerülnek. (SID_1) 